\title{
Standard Costing and Cost Control in Nigerian Oil and Gas Industry
}

\author{
Cletus O. Akenbor \\ Federal University, Otuoke, Nigeria \\ Thankgod C. Agwor \\ Rivers State University of Science and Technology, Port Harcourt, Nigeria
}

\begin{abstract}
The purpose of this study was to investigate the relationship between standard costing and cost control in Nigerian oil and gas industry. This was achieved through a review of extant literature and development of hypotheses. The population for the study consisted of petroleum marketing companies listed in the Nigerian Stock Exchange Factbook of 2012. In order to generate the necessary data for this study, both primary and secondary methods of data collection were adopted. The primary data were collected through the administration of a questionnaire designed in a 5-point Likert scale, while the secondary data were sourced from the Nigerian Stock Exchange Factbook of 2011. The findings generated in this study revealed that a significant relationship exists between standard costing and cost control. It was observed that the more a firm practices standard costing, the more efficient is the firm in material, labor, and overhead costs. Based on the above findings, we recommended that oil and gas firms in Nigeria should adopt and apply standard costing in their accounting system so as to ensure the efficient use of resources for an effective control of costs.
\end{abstract}

Keywords: standard costing, cost control, variance, actual, cost

\section{Introduction}

The overall objective of a business organization is the realization of profit. Profitability can be achieved basically in two ways: the maximization of revenue and the minimization of operating costs. Likert and Seashore (1998) argued that profit maximization is best achieved through cost minimization rather than the maximization of revenue. They further explained that most of the decisions made by management hinge on cost incurred for various activities. If profitability is to be realized through cost minimization, then management must control operating costs. In each of the decision-making situations, managers are expected to exert some control on the magnitude of costs incurred. Specifically, operating managers must ensure that: (1) The prices of materials procured are as low as possible; (2) The quantity of materials consumed during the production period should not be excessive; (3) The labor cost incurred is commensurate with output achieved; and (4) The rate of production maintained by workers must be that which will achieve the targeted level of production.

One of the cost accounting techniques used by management to control cost (i.e., cost minimization) is the standard costing technique. Braide (2002) defined standard costing as the cost accounting technique, which

Cletus O. Akenbor, Ph.D., Department of Accounting and Finance, Federal University. Email: akenborcletus@yahoo.com.

Thankgod C. Agwor, Ph.D., Department of Accountancy, Rivers State University of Science and Technology. 
attempts to determine what the cost of manufacturing a product or rendering a service will be during a given specified future period. The pre-determined cost of manufacturing a product or providing a service is described as standard cost. Standard costing system is an internal cost control system used by organizations whereby a cost standard is determined, which has to be compared periodically with actual cost. In most cases, differences occur between the standard costs and the actual costs. Therefore, management is saddled with the responsibility to ensure that actual costs do not exceed the standard costs. However, the difference between actual costs and standard costs is known as variance. Dean (1948) stated that variances disclose those spheres of operation where actual results achieved and experienced are not exactly the same as planned, irrespective of whether actual results are better or worse than planned achievements. The computation and analysis of cost variances are of inestimable value to management since such analysis reveals not only the causes but also their magnitudes.

Standards set are mere anticipations, which are expected to take effect during a specified period of operation. Actual events experienced may or may not coincide with the standards set. For example, the price at which materials are actually purchased may not be the same as the anticipated standard price, the rate of production actually attained by workers may exceed or fall short of the standard rate, the rate of consumption of materials in production may be more or less than that envisaged in the standard, the actual labor cost may differ from the standard cost of labor, and the actual overhead costs may not equally be the same with standard. It is on this premise that this study is consummated to investigate the relationship between standard costing and cost control. Hence, it was hypothesized that standard costing has no significant relationship with cost control in the Nigerian oil and gas industry.

\section{Cost Control}

Cost is any monetary sacrifice made to secure a benefit. Without cost, there can be no productive activity that will generate the profitability objective of the firm. Empirical results have shown that in many organizations, operating costs are unnecessarily high, thereby robbing the organization of the profit that would have been made (Yoshikawa, Innes, Mitchell, \& Tanaka, 1993). In order to ensure that costs are brought to the barest minimum, there is a need for cost control. According to Bromwich (2000), cost control is the process of setting cost standard, measuring actual result, comparing actual cost with the standard cost, and taking corrective actions where deviations exist. Adeniji (2004) stated that cost control is the regulation of cost of operating a business and is concerned with keeping costs within acceptable limits. These limits will usually be specified as a standard cost or target cost limit in a formal operational plan or budget. If actual cost differs from planned cost by an excessive amount, cost control action will be necessary. You might like to think of cost control as an exercise in good housekeeping by avoiding a wasteful use of valuable resources and encouraging efficiency and cost consciousness (Adeniji, 2004).

Ukpai (1999) posited that cost control action ought to lead to a reduction in excessive spending, for example, when material wastage is higher than budget or productivity level is below agreed standards. A cost reduction programme, however, can be directed towards reducing expected cost level by cutting cost to below current standard level by purchasing new equipment, changing methods and techniques of production, and so on. However, standards reflect current costs and conditions and not necessarily the cost and conditions which would minimize costs (Ukposido, 2002). 
Adeniji (2004) noted that one way of reducing cost is to improve the efficiency of material usage, the productivity of labor, or the efficiency of machinery or other equipment. There are several ways in which this might be done: (1) improved materials, where wastage is currently high. Wastage might be reduced by changing the specifications for cutting the materials; introducing new equipment that reduces wastage in processing or handling of materials; identifying poor quality output at an earlier stage in operational processes; and using a better quality of materials. Ukposido (2002) noted that even if high-quality materials are more expensive, they might save costs because they are less likely to tear and they last longer; (2) labor productivity can possibly be improved by giving pay incentives for better productivity; changing work methods to eliminate unnecessary procedures and make a better use of labor time; changing work patterns or schedules so as to smoothen out seasonal fluctuations over the year and reduce the need for overtime payments as the height of seasonal production. This can also reduce non-conformance quality costs, that is, the cost of faulty goods produced under pressure during unrealistically high overtime periods; improving the methods for achieving cooperation between group and departments; and setting more challenging standards of efficiency. Given the right motivation among the workforce, more challenging standards will encourage greater effort; and (3) improving the efficiency of equipment usage might involve: making a better use of equipment resources and achieving a better balance between preventive maintenance and machine "down-time” for repairs.

Different accounting techniques are available for cost control among which are standard costing, budgeting, and responsibility accounting (Atkinson, Banker, Kaplan, \& Young, 1995).

\section{Standard Costing}

Standard costing is an integral part of management accounting control technique, which has to do with the process of estimating the total cost of production per unit (Emmanuel, Otley, \& Merchant, 1990). The operation of a standard costing system presupposes the existence of an in-built mechanism whereby actual costs incurred are periodically compared with the standard costs. The standard costs are costs which should have been incurred on the basis of output actually produced. Braide (2002), however, noted that the standard costs may differ from the actual costs incurred in producing the actual output. A comparison of the standard costs against the actual costs will disclose a difference and managers are expected to take appropriate actions to make actual costs conform with standard costs, if the comparison of the action costs and the standard costs reveals that actual costs have exceeded standard costs. The differences between actual costs and standard costs are termed variances.

Barrett and Fraser (1977) stated that where the objective of management is to control cost of materials, a standard should be set for material cost; where management is concerned with labor cost control, a standard has to be set for labor cost; and where management attention is on overhead cost control, a standard must be set for overhead cost. These set standards are used as monitoring devices to ensure that the actual costs incurred on materials, labors, and overheads are not excessive. For instance, if the standard cost of material is set at N5,000, (i.e., the price of the material $\mathrm{N} 50 \times$ quantity of material usage 100 units). This set standard of material cost will serve as a guide to managers in the following ways: (1) Price of the material must not exceed N50; and (2) Quantity of material usage must not exceed 100 units. However, where managers find it difficult to purchase the material for N50 per unit, e.g., N60, then the actual cost of material $(\mathrm{N} 60 \times 100=\mathrm{N} 6,000)$ may exceed the standard cost of N5,000. The difference of N1,000 is the variance, which is as a result of the price increase. Standard costing, therefore, creates an atmosphere of cost-consciousness amongst all levels of 
workers by motivating them to see if there is a better way of performing a particular task (Horngren, Foster, \& Dater, 1994).

In spite of the numerous benefits gained by an organization from the use of standard costing technique, this technique for cost control is bedeviled by so many drawbacks, which include: the establishment of a standard that is in most cases unattainable; the problem of identifying the specific needs of consumers; persistent increase in general price level; frequent changes in the level of technology; political instability and changes in government; changes in macro-economic policies; problems associated with the accurate estimation of normal loss in the course of production; variation in labor rate per hour among different organizations which depends on other economic variables; and operating managers' negative attitudes towards the established standards (Yoshikawa et al., 1993; Dean, 1948).

The operation of a standard costing system presupposes that a company wishes to ascertain the standard costs incurred while manufacturing its products. Hart (1981) stated that such a system will require maintaining records whereby all the elements of cost will be stated at standard. In his illustration, he explained that materials procured for the purposes of production will be recorded at standard cost, labor expended upon production will be recorded at standard cost, and manufacturing overheads will also be recorded at standard cost. It is inevitable, however, that some aspects of the transactions will have to be recorded at actual costs. For example, the account of the supplier of materials procured will be credited at the actual purchase cost irrespective of the fact that this purchase cost was more or less than the standard material cost. Similarly, the amount earned by workers will be credited to them even though this amount may be more or less than the standard labor cost; also, we shall credit the accounts of all overhead expense creditors' account with the actual amounts due them whether or not these amounts are more or less than the standard overhead cost.

Although a company adopts a number of methods in recording costs under a system of standard costing, in this study, we reviewed the method whereby all expenses incurred are recorded at actual cost in the first instance in their respective accounts. Transfers from such accounts to the production account or work-in-progress account will be effected at standard costs. For example, direct materials purchased will be debited to the stores' ledger control account at actual cost and credited to the suppliers or creditors' account at actual cost. However, materials issued from stores to production will be debited to the work-in-progress account at standard cost and credited to the stores ledger control account at actual cost. The difference if any, between the actual and standard purchase prices of the material, will either be debited or credited to a material price variance account. It will be a rare coincidence for the actual price paid for direct materials purchased to be the same as the standard price set prior to commencement of operation. More often than not, either the actual price paid will be more or less than the standard price proposed to be paid or the standard price will be more or less than the actual price. Since the company is operating a standard costing system, the material issued to production will be debited to the work-in-progress account at the standard cost. In other words, any difference between the actual price and standard price of material will be eliminated so that material consumed in production will be charged to the work-in-progress account at standard price (Amigoni, 1978).

Adeniji (2004) defined variance as the difference between the standard cost of production and the actual cost of production or the difference between the budgeted revenue and the actual revenue. Rotch and Allen (1982) stated that variance is the deviation of actual from expected. Several factors are responsible for the differences between standard costs and actual costs. These factors are associated with the price of materials, material usage, labor rate, labor efficiency, and overheads. 


\section{Methodology}

The population of the study consisted of seven oil and gas companies in the Niger-Delta region of Nigeria whose offices are located in Port Harcourt, the Rivers State capital. In order to generate the necessary data for the study, a questionnaire designed in a 5-point Likert scale ranging from 5 (strongly agree) to 1 (strongly disagree) was administered on five accounting staff in each of the seven selected companies, resulting in a total of 35 questionnaires administered.

The data generated from the study were analyzed using the mean index, while the stated hypothesis was tested with linear regression. The linear regression model is specified as follows:

$$
C O C=a+b S C+U_{i}
$$

where:

COC $=$ Cost control;

$S C=$ Standard costing;

$a=$ Regression constant;

$b=$ Regression coefficient;

$U_{i}=$ Error term.

\section{Empirical Analysis}

This section of the study focused on a descriptive analysis of the variables of the study and a test of hypothesis.

Table 1

Degree of the Practice of Standard Costing

\begin{tabular}{|c|c|c|c|c|c|c|c|}
\hline No. & Measure of standard costing & A (4) & $\mathrm{U}(3)$ & $\mathrm{D}(2)$ & $\mathrm{SD}(1)$ & Total & $\bar{X}$ \\
\hline 1 & $\begin{array}{l}\text { The company sets standard output for the } 1 \text { (5) } \\
\text { various products it manufactures. }\end{array}$ & $3(12)$ & $6(18)$ & $14(28)$ & $11(11)$ & $35(74)$ & 2.11 \\
\hline 2 & $\begin{array}{l}\text { The company sets a standard for the } 2 \text { (10) } \\
\text { quantity of materials to be used for } \\
\text { production. }\end{array}$ & $7(28)$ & $1(3)$ & $13(26)$ & $12(12)$ & $35(79)$ & 2.26 \\
\hline 3 & $\begin{array}{l}\text { The company sets a standard for the } 8(40) \\
\text { purchase price of the required materials. }\end{array}$ & $10(40)$ & $5(15)$ & $8(16)$ & $4(4)$ & 35 (115) & 3.29 \\
\hline 4 & $\begin{array}{l}\text { The company sets a standard for the } 3(15) \\
\text { quantities of various ingredients of the } \\
\text { intended finished products. }\end{array}$ & $5(20)$ & $2(6)$ & $17(34)$ & $8(8)$ & $35(83)$ & 2.37 \\
\hline 5 & $\begin{array}{l}\text { The company sets a standard of the number } 5 \text { (20) } \\
\text { of hours required of labor to produce a unit } \\
\text { of the finished product. }\end{array}$ & $3(12)$ & $4(12)$ & $16(32)$ & $7(7)$ & $35(83)$ & 2.37 \\
\hline 6 & $\begin{array}{l}\text { The company sets a standard rate at which } 7 \text { (35) } \\
\text { labor will be remunerated. }\end{array}$ & $7(28)$ & $6(18)$ & 9 (18) & $6(6)$ & $35(105)$ & 3.0 \\
\hline 7 & $\begin{array}{l}\text { The company sets a standard as to the } 6(30) \\
\text { number of products that should be produced } \\
\text { within a given time frame. }\end{array}$ & $4(16)$ & $0(0)$ & $20(40)$ & $5(5)$ & $35(91)$ & 2.60 \\
\hline 8 & $\begin{array}{l}\text { The company sets a standard of variable } 4 \text { (20) } \\
\text { overhead that is directly proportional to the } \\
\text { level of activity. }\end{array}$ & $5(20)$ & $1(3)$ & $15(30)$ & $10(10)$ & $35(83)$ & 2.37 \\
\hline \multirow[t]{2}{*}{9} & $\begin{array}{l}\text { The company sets a standard for all the } 3(15) \\
\text { indirect manufacturing expenses. }\end{array}$ & $2(8)$ & $2(6)$ & $16(32)$ & $12(12)$ & 35 (73) & 2.09 \\
\hline & Average & & & & & & 2.50 \\
\hline
\end{tabular}

Notes. Source: Field Work (2014). SA: Strongly agree; A: Agree; U: Undecided; D: Disagree; and SD: Strongly disagree. 
The data presented in Table 1 above revealed the following findings:

(1) On whether the company sets standard output for the various products it manufactures, we found a mean index of 2.11, which is less than 3.0 on a 5-point scale. This implies that the companies do not set standard output for the various products they manufacture;

(2) A mean index of 2.26, which is less than 3.0 on a 5-point scale, was found on the issue of whether the company sets a standard for the quantity of materials to be used for production. This suggests that no standard is set for the quantity of materials to be used for production;

(3) We observed a mean index of 3.29 on whether the company sets a standard of the purchase price of the required materials. Since the mean index is greater than 3.0 on a 5-point scale, it is concluded that the company sets a standard of the purchase price of the required materials;

(4) It was gathered in this study that no standard for the quantities of various ingredients of the intended finished products is set by the company. This conclusion is based on the fact that a mean index of 2.37, which is less than 3.0 on a 5-point scale, was revealed on this issue;

(5) On whether the company sets a standard of the number of hours required of labor to produce a single unit of a product, we found a mean index of 2.37, which is less than 3.0 on a 5-point scale. This implies that no standard is set by the company on the number of hours required of labor to produce a single unit of a product;

(6) On whether the company sets a standard rate at which labor will be remunerated, we found a mean index of 3.0, which is equivalent to 3.0 on a 5-point scale. This suggests that there is no clear-cut position of the company on whether a standard rate of labor remuneration is set or not;

(7) We obtained a mean index of 2.60, which is less than 3.0 on a 5-point scale on the issue of setting a standard of the number of products that should be produced within a given time frame. This confirms that no standard is set by the company in terms of the number of products that should be produced within a given time frame;

(8) A mean index of 2.37, which is less than 3.0 on a 5-point scale, was found on the issue of whether the company sets a standard of variable overhead that is directly proportional to the level of activity. This suggests that no such standard is set;

(9) It was gathered in this study that no standard is set by the company for all the indirect manufacturing expenses. This conclusion is based on the fact that a mean index of 2.09, which is less than 3.0 on a 5-point scale, was revealed on this issue.

In summary, the variable measures of standard costing revealed a mean index of 2.50, which is less than 3.0 on a 5-point scale. This is a clear indication that the adoption of standard costing by the companies is low.

The data presented in Table 2 below revealed the following findings:

(1) On whether the quantity of materials used for production by the company is usually less than expected, we obtained a mean index of 1.69 , which is less than 3.0 on a 5 -point scale. This implies that the quantity of materials used for production by the company is not usually less than expected;

(2) A mean index of 2.17, which is less than 3.0 on a 5-point scale, was found on the issue of whether the purchase price of materials in the company is often less than the estimated price. This confirms that the purchase price of materials is not often less than estimated;

(3) We observed in this study that the company had no clear-cut position on whether the actual quantity of the various ingredients used for production is usually less than the target. This conclusion is due to the fact that a mean index of 3.0, which is equivalent to 3.0 on a 5-point scale, was revealed on this issue; 
(4) On whether the hours of labor used in producing a single unit of a product in the company are less than expected, we obtained a mean index of 2.29 , which is less than 3.0 on a 5 -point scale. This implies that the hours of labor used in producing a single unit of a product by the company are greater than expected;

(5) In this study, it was observed that the estimated rate of labor remuneration is usually not less than the actual rate. This conclusion is based on the fact that a mean index of 2.34, which is less than 3.0 on a 5-point scale, was revealed on this issue;

(6) A mean index of 2.03, which is less than 3.0 on a 5-point scale, was found on the issue of whether the variable overhead expenses incurred by the company are usually less than expected. This suggests that the variable overhead expenses incurred by the company are not usually less than expected;

(7) On whether the expected indirect expenses of the company are less than that incurred, we obtained a mean index of 3.43, which is greater than 3.0 on a 5-point scale. This confirms that the expected indirect expenses of the company are less than that incurred;

(8) We obtained a mean index of 3.0, which is equivalent to 3.0 on a 5-point scale on the issue of whether the established quantity of a product to be produced by the company is less than the actual production volume. This implies that there is no clear-cut position of the company on whether the established quantity of a product to be produced by the company is less than the actual production volume.

In summary, the variable measures of cost control by the company revealed a mean index of 2.49 , which is less than 3.0 on a 5-point scale. Hence, it is concluded that the extent of cost control by the companies is low.

Table 2

The Degree of Cost Control by the Companies

\begin{tabular}{|c|c|c|c|c|c|c|c|c|}
\hline $\mathrm{S} / \mathrm{N}$ & Measure of cost control & SA (5) & A (4) & $\mathrm{U}(3)$ & $\mathrm{D}(2)$ & SD (1) & Total & $X$ \\
\hline 1 & $\begin{array}{l}\text { Quantity of materials used or } \\
\text { production by the company is } \\
\text { usually less than expected. }\end{array}$ & $0(0)$ & $2(8)$ & $4(12)$ & $10(20)$ & 19 (19) & 35 (59) & 1.69 \\
\hline 2 & $\begin{array}{l}\text { The purchase price of materials in } \\
\text { the company is often less than the } \\
\text { estimated price. }\end{array}$ & $3(15)$ & $6(24)$ & $1(3)$ & $9(18)$ & $16(16)$ & $35(76)$ & 2.17 \\
\hline 3 & $\begin{array}{l}\text { The actual quantity of the various } \\
\text { ingredients used for production in } \\
\text { the company is usually less than } \\
\text { the target. }\end{array}$ & 7 (35) & $7(28)$ & $6(18)$ & $9(18)$ & $6(6)$ & 35 (105) & 3.0 \\
\hline 4 & $\begin{array}{l}\text { The hours of labor used in } \\
\text { producing a single unit of a } \\
\text { product in the company are less } \\
\text { than expected. }\end{array}$ & $4(20)$ & $3(12)$ & $2(6)$ & $16(32)$ & $10(10)$ & $35(80)$ & 2.29 \\
\hline 5 & $\begin{array}{l}\text { The estimated rate of labor } \\
\text { remuneration is usually less than } \\
\text { the actual rate in the company. }\end{array}$ & $2(10)$ & $5(20)$ & $5(15)$ & $14(28)$ & $9(9)$ & $35(82)$ & 2.34 \\
\hline 6 & $\begin{array}{l}\text { The variable overhead expenses } \\
\text { incurred by the company are } \\
\text { usually less than expected. }\end{array}$ & $2(10)$ & $2(8)$ & $2(6)$ & $18(36)$ & $11(11)$ & $35(71)$ & 2.03 \\
\hline 7 & $\begin{array}{l}\text { The expected indirect expenses of } \\
\text { the company are less than that } \\
\text { incurred. }\end{array}$ & $10(50)$ & $12(48)$ & $0(0)$ & $9(18)$ & $4(4)$ & 35 (120) & 3.43 \\
\hline 8 & $\begin{array}{l}\text { The established quantity of a } \\
\text { product to be produced by the } \\
\text { company is less than the actual } \\
\text { production volume. }\end{array}$ & $9(45)$ & $7(28)$ & $1(3)$ & $11(22)$ & $7(7)$ & 35 (105) & 3.0 \\
\hline & Average & & & & & & & 2.49 \\
\hline
\end{tabular}

Notes. Source: Field Work (2014). SA: Strongly agree; A: Agree; U: Undecided; D: Disagree; and SD: Strongly disagree. 
In testing the hypothesis in this study, the respondents' perception index on standard costing was regressed against the perception index on cost control and the result obtained is presented in Table 3.

Table 3

The Relationship Between Standard Costing and Cost Control

\begin{tabular}{|c|c|c|c|c|c|}
\hline \multirow{2}{*}{ Model } & \multicolumn{2}{|c|}{ Unstandardized coefficient } & \multirow{2}{*}{$\begin{array}{l}\text { Standardized coefficient } \\
\text { Beta }\end{array}$} & & \multirow{2}{*}{ Sig. } \\
\hline & $\bar{B}$ & Std. error & & & \\
\hline 1 (constant) & 3.126 & 0.729 & & 4.197 & \\
\hline Social cost & 0.018 & 0.068 & 0.637 & 2.648 & 0.025 \\
\hline
\end{tabular}

Note. Source: Statistical Package for Social Sciences (SPSS) Version 16 Window output.

The result presented in Table 3 revealed a correlation coefficient $(R)$ of 0.637 , which is close to 1.0 from the positive side. This suggests a positive relationship between standard costing and cost control. The coefficient of determination $\left(R^{2}\right)$ of 0.406 suggests that about $40.6 \%$ increase in cost control is associated with increase in the adoption of standard costing. The $P$-value (0.025), which is less than 0.05 at the confidence level of $95 \%$ for a two-tailed test, indicates a significant relationship. This confirms that standard costing has a significant relationship with cost control in the companies.

\section{Conclusion and Recommendations}

On the basis of the above analysis and findings, the following conclusion could be drawn with regard to the use of standard costing for cost control in the oil and gas industry in Nigeria.

Standard costing is an effective instrument of cost control in the oil and gas industry in Nigeria. It helps to monitor the performance of workers, creates an environment of cost consciousness, helps management to reappraise operating activities to ascertain cost effectiveness, serves as a source of motivation for staff to achieve set standards, and provides a basis of control for the purchase and usage of materials and work levels. Although a significant relationship exists between standard costing and cost control, the application of standard costing for cost control in the oil and gas industry in Nigeria is at low ebb, and this accounts for one of the reasons why operational cost in the oil and gas industry in Nigeria is excessively high.

With regard to the findings made in this study, we therefore recommend that management should devise appropriate strategic measures for the adoption of standard costing to enhance efficiency in material, labor, and overhead costs. They should also pattern their operations in line with the environmental factors that hinder the effective use of standard costing, such as economic policies, political instability, changes in government, changes in technology, changes in general price level, etc.. These environmental factors should be carefully studied by management so that a reasonable forecast of possible changes in the environment can be made.

\section{References}

Adeniji, A. A. (2004). An insight into management accounting. Lagos: Value Analysis Consult.

Amigoni, F. (1978). Planning management control systems. Journal of Business Finance and Accounting, 5(3), 279-291.

Atkinson, A., Banker, R. D., Kaplan, R. S., \& Young, S. M. (1995). Management accounting. Irwin: Prentice Hall.

Barrett, M. E., \& Fraser, L. B. (1977). Conflicting roles in budgeting for operations. Boston: Harvard Business School Press.

Braide, J. J. M. (2002). The theory and practice of management accounting. Owerri: Springfield Publishers.

Bromwich, M. (2000). Standard costing for planning and control. In J. Arnold, B. Carsberg, \& R. Scapens (Eds.), Topics in management accounting (p. 193). Oxford: Philip Allen.

Dean, J. (1948). Cost structures of enterprises and break-even charts. The American Economic Review, 38(2), 153-164.

Emmanuel, C., Otley, D. T., \& Merchant, K. (1990). Accounting for management control. London, UK: Chapman and Hall. 
Hart, H. A. (1981). A review of some recent major developments in the management accounting field. Accounting and Business Research, 11(42), 99-115.

Horngren, C. T., Foster, G., \& Dater, S. M. (1994). Cost accounting: A managerial emphasis. Englewood Cliffs, NJ: Prentice Hall. Likert, R., \& Seashore, S. E. (1998). Making cost control work. In D. Solomon (Ed.), Studies in cost analysis. London: Sweet and Maxwell.

Rotch, L., \& Allen, P. (1982). Advanced management accounting. Boston: Harvard Business School Press.

Ukpai, N. A. (1999). Basic managerial accounting. Port Harcourt: Pen Paper Publishers.

Ukposido, S. U. (2002). Conceptual foundations of cost accounting. New York, NY: Addison-Wesley.

Yoshikawa, T. J., Innes, J., Mitchell, F., \& Tanaka, M. (1993). Contemporary cost management. London, UK: Chapman and Hall. 